\title{
Postharvest mechanical damage affects fruit quality of 'Montenegrina' and 'Rainha' tangerines
}

\author{
Cândida Raquel Scherrer Montero(1), Lígia Loss Schwarz(1), Liege Cunha dos Santos(1), \\ Cristiane Salete Andreazza ${ }^{(1)}$, Carolina Pereira Kechinski( ${ }^{(2)}$ and Renar João Bender ${ }^{(1)}$
}

\begin{abstract}
(1)Universidade Federal do Rio Grande do Sul (UFRGS), Faculdade de Agronomia, Departamento de Horticultura, Caixa Postal 15.100 CEP 91540-000 Porto Alegre, RS, Brazil. E-mail: candidaraquel@gmail.com, liegesantos@ibest.com.br, crisandreazza@hotmail.com, rjbe@ufrgs.br (2)UFRGS, Escola de Engenharia, Departamento de Engenharia Química, CEP 90040-040 Porto Alegre, RS, Brazil. E-mail: carolpk@enq.ufrgs.br
\end{abstract}

\begin{abstract}
The objective of this work was to evaluate the visual and chemical quality of tangerines after mechanical damage by impacts. The tangerine cultivars Montenegrina and Rainha were submitted to different degrees of impact and evaluated for decay and oleocellosis, loss of fresh weight, total soluble solids, total titratable acidity and ascorbic acid degradation, as well as for epicarp color changes. Experiments with three replicates and experimental units of six fruit for each cultivar were done in a completely randomized design. Impact produced qualitative internal and minor external changes on tangerines. The main modifications produced by impact on the fruit were losses of citric acid and soluble solids, which increased the solid:acid ratio, and losses of ascorbic acid. 'Montenegrina' tangerines are more susceptible to internal quality damage than 'Rainha'.
\end{abstract}

Index terms: Citrus deliciosa, flavor loss, nutritional loss, physical damage.

\section{Danos mecânicos na pós-colheita afetam qualidade de frutos de tangerinas 'Montenegrina' e 'Rainha'}

\begin{abstract}
Resumo - O objetivo deste trabalho foi avaliar a qualidade visual e química de tangerinas, após danos mecânicos por impacto. As cultivares de tangerina 'Montenegrina' e 'Rainha' foram submetidas a diferentes graus de impacto e avaliadas quanto à oleocelose e podridão, perda de massa de matéria fresca, sólidos solúveis totais, acidez total titulável e degradação do ácido ascórbico, bem como mudanças na cor do epicarpo. Os experimentos consistiram de três repetições de seis frutos, para cada cultivar, e o delineamento foi inteiramente casualizado. Os impactos produziram mudanças qualitativas internas nas tangerinas, mas as mudanças externas foram mínimas. As modificações mais importantes, produzidas por impacto nas frutas, foram as perdas de ácido cítrico e sólidos solúveis, o que aumentou a relação sólidos:acidez, e as perdas de ácido ascórbico. A tangerina da cultivar Montenegrina é mais susceptível a danos qualitativos internos do que a 'Rainha'.
\end{abstract}

Termos para indexação: Citrus deliciosa, perda de sabor, perda nutricional, dano físico.

\section{Introduction}

Brazil is the world's largest producer of citrus fruit, with 20 million megagrams per year (Instituto FNP, 2008). According to Pio et al. (2005), tangerines and their hybrids are highly susceptible to injuries due to harvest and post harvest handling and transportation, and these injuries serve as an entrance to pathogens.

From production to consumption, horticultural products are prone to the action of static and dynamic forces during the operations and to processing to which they are submitted (Couto et al., 2002). Mechanical damage is extremely common during fruit handling, and is defined as plastic deformation, superficial rupture and destruction of vegetable tissue due to external forces (Sanches et al., 2008). The effects of mechanical injury in citrus fruit are not always as evident as they are in other species. In apples and similar fruit, tissue oxidation shows the injury, and the fruit loss is almost immediate. Therefore, there is less concern in citrus fruit handling to avoid mechanical damage to fruit.

Physical impact is of the most common cause of mechanical damage. According to Vignealt et al. (2002) impacts are transitory movements caused by sudden acceleration or deceleration causing great dissipation of energy and consequent damage to the fruit. During packing, fruit and vegetables are more exposed to impact and vibration than to compression forces (Garcia et al., 1988). 
Some of the effects of mechanical damage are related to internal quality loss with flavor and nutritional modification, as reported by Durigan et al. (2005) for 'Tahiti' limes. For other fruit, such as tomato, guava, mango and peach, research shows loss of acid content during mechanical stress (Moretti et al., 1998; Mattiuz \& Durigan, 2001; Durigan et al., 2005; Kasat et al., 2007). Loss of vitamin $C$ has also been reported for tomato (Moretti, 1999). External modification is more common on fruit that show oxidation of the pulp, like apple or peach, but can also occur on the rind of citric species with the rupture of oil glands and the development of oleocelloses (Fischer et al., 2007).

The objective of this work was to evaluate the visual and chemical quality of tangerines after mechanical damage by impacts. Tissue responses to varying degrees of impact were assessed as well, to understand responses of citrus fruit to mechanical stress.

\section{Materials and Methods}

'Montenegrina' and 'Rainha' tangerines were harvested from private groves and transported by car on the same day to the postharvest laboratory located at Departamento de Horticultura in Porto Alegre, RS, Brazil. The harvested tangerines were submitted to different degrees of impact by letting the fruit fall from $40,60,80$ or $100-\mathrm{cm}$ heights. Each fruit was dropped twice from the same height onto a rigid ceramic surface. There were three replicates, with six fruits for each experimental unit for each cultivar, in a completely randomized design.

After the treatments, the fruit were maintained at room temperature $\left(20 \pm 2^{\circ} \mathrm{C}\right)$ for seven days and were then analyzed for weight loss, rot and oleocelloses incidence, total titratable acidity (TA), total soluble solids (TSS), ascorbic acid content and external color by the methods described below. All six fruit of each replicate were used to obtain weight loss, rot and oleocelloses incidence. For color assessment, three readings were obtained per fruit on opposite equatorial regions of three fruit.

At the last day of the experiment, five fruit of each replicate were used to obtain the juice for the chemical analyses, which were replicated twice for each sample. The TA was determined in percentage of citric acid, by titration of $10 \mathrm{~mL}$ of juice diluted in $90 \mathrm{~mL}$ distilled water with $\mathrm{NaOH}$ $0.1 \mathrm{~N}$ until pH 8.1 by the method no. 942.15 (AOAC International, 2002). TSS was determined with a pocket refractometer (Atago, Pal-1, Tokio, Japan), and the readings were corrected for $20^{\circ} \mathrm{C}$, according to the method no. 932.12 (AOAC International, 2002). Fresh weight loss was determined by mass difference at the beggining and end of the experiment and expressed as percentage of the initial fruit mass.

Epicarp color of the equatorial areas of the tangerines was determined with a Konica/Minolta colorimeter, model CR400 (Mahwah, NJ, USA). The results of the $\mathrm{L}^{*}$ (luminosity), $\mathrm{a}^{*}$ and $\mathrm{b}^{*}$ color parameters were accessed through three readings and used to obtain the hue and chroma values, which are indicators of color modification and vividness respectively. Both values were calculated by the following equations: Chroma $=\left(a^{2}+b^{2}\right)^{1 / 2}$; Hue $=[\operatorname{arcotang}(\mathrm{a}, \mathrm{b}) \times 180] / \pi($ Minolta, 1993) .

Decay was determined as the number of fruit with visible symptoms of pathogens - by visual observation of green or blue Penicillium sp. molds - and expressed as percentage of rotten fruit of six fruit. Oleocellosis was assessed by the number of fruit with visible symptoms of epicarp color alterations and with characteristic depressions in the rind. Oleocellosis incidence was expressed in percentage of fruit with symptoms of the disorder.

Ascorbic acid contents was determined as L-ascorbic acid via photocolorimetric reaction with 2,6-diclorofenol indofenol dye. A 2-mL sample of citrus fruit juice was diluted in $100 \mathrm{~mL}$ of oxalic acid $(4: 1,000)$ and filtered through Whatman filter paper grade $1 ; 1.1 \mathrm{~mL}$ of EDTA $\left(0.1 \mathrm{~mol} \mathrm{~L}^{-1}\right)$ was added to stabilize the ascorbic acid. A 10-mL aliquot of this extract was mixed with $3 \mathrm{~mL}$ sodium citrate buffer (pH 4.5) (Fernandez et al., 2007; Kechinski, 2007). A $1.5-\mathrm{mL}$ aliquot of the final extract was then added to $1.5 \mathrm{~mL}$ of the dye solution and mixed in a disposable polystyrene cuvette. Sample absorbance was read at $530 \mathrm{~nm}$ on a UV-VIS spectrophotometer (model T6, PG Instruments, London, UK).

Data were submitted to ANOVA and to regression analysis. When significant, averages were compared by Duncan's multiple range test at $5 \%$ of probability. To run the statistical analysis, the SAS program (SAS Institute, 2004) was used. 


\section{Results and Discussion}

Impact treatments on tangerines did not enhance the incidence of decay in 'Montenegrina' and 'Rainha' tangerines. Averages of fresh weight loss did not differ from the control by variance analysis, but increases in fresh weight losses are explained by the treatment intensity only for 'Rainha' tangerines (Figure $1 \mathrm{~A}$ ). Responses in terms of fresh weight loss vary according to the species and conditions studied. Kasat et al. (2007) observed that impact increased weight loss in 'Aurora-1' peaches. Sanches et al. (2008) did not find response for increase in fresh weight loss of avocados in impact treatments. Studies with 'Tahiti' lime show cuts as the most harmful damage concerning weight loss, followed by impact and compression (Durigan et al., 2005).

Total titratable acidity of tangerine cultivar Montenegrina was significantly affected by impact treatments (Figure $1 \mathrm{~B}$ ). Titratable acidity varied according to the drop height applied. The reductions were of up to $24 \%$ for 'Montenegrina'. Soluble solids
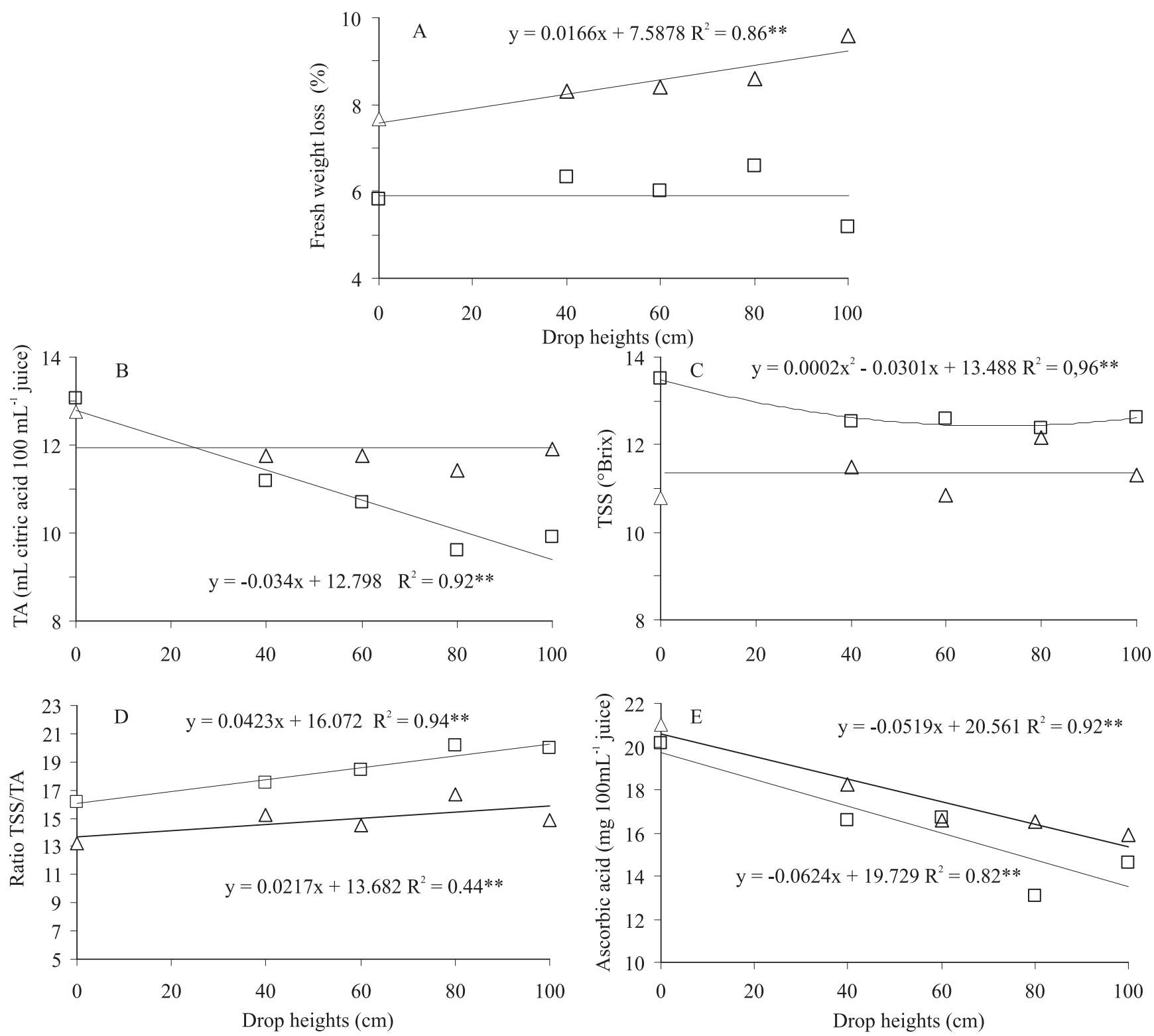

Figure 1. Regression equation for A, fresh weight loss; B, titratable acidity (TA); C, total soluble solids (TSS); D, ratio TSS/TA; and $\mathrm{E}$, ascorbic acid of tangerines 'Montenegrina' $(\square)$ and 'Rainha' $(\Delta)$ submitted to impact drops (cm). **Significant at $1 \%$ probability. 
also decreased for 'Montenegrina' tangerines, whereas for 'Rainha' there was no significant response.

The ratio between total soluble solids and acids increases with the increase in drop heights, especially for 'Montenegrina' tangerines (Figure 1 D). This result is associated with the reduction in the acid content showed above. Increases in ratio values indicate that the tangerines are more senescent with noteworthy flavor modifications (Mattiuz et al., 2003). According to these authors, fruit becomes less tasty because of sugar accumulation or acid reduction or both, and acquire an overripe flavor.

Impact significantly reduced soluble solids and titratable acidity of 'Tahiti' limes, reflecting the effect of stress on the fruit (Durigan et al., 2005). Similar results were found by Mattiuz \& Durigan (2001) working with guava, by Sanches et al. (2008) for avocado, and by Moretti et al. (1999) for tomato. According to Sanches et al. (2008), the reduction of soluble solids can be explained by the use of these elements as a source of energy. Acids are also a great energy source for the oxidation process in the Krebs cycle (Kays, 1991). Organic acids are usually reduced with maturation due to respiration and are converted into sugar (Mattiuz et al., 2003). Plant organs submitted to vibration or mechanical damage usually increase their respiration rates in comparison to uninjured controls (Pisarczyk, 1982; Salveit \& Locy, 1982; Mao et al., 1995). Therefore, the impact treatments tested here could be accelerating the oxidation of acids by the enhancing respiration. More research on the response of respiration to mechanical damage, in this species, is necessary to prove this hypothesis.

Ascorbic acid content varied with the mechanical damage applied (Figure $1 \mathrm{E}$ ). Reductions of 35 and $24 \%$ in vitamin C were found for 'Montenegrina' and 'Rainha' tangerines respectively. Durigan et al. (2005) found a decrease of approximately $6 \%$ of vitamin $\mathrm{C}$ in 'Tahiti' limes submitted to impact. According to these authors, neither compression nor cuts affected vitamin C contents. In tomato, a decrease of $17 \%$ in vitamin $\mathrm{C}$ was determined in injured fruit (Moretti et al., 1999). The author concluded that injured tomato tissues had smaller amounts of organic acids and vitamin $\mathrm{C}$, and that the locular tissue was the most affected by impact.

According to Nagy (1980) most of the ascorbic acid is lost after harvest due to aerobic reactions. In fruit endocarp, the enzymatic break down is smaller because of the lower enzyme concentration, especially of poliphenol oxidases. Silva et al. (2006), studying the effect of processing on vitamin $\mathrm{C}$ contents in orange juice, concluded that stirring the juice significantly reduced the amounts of the vitamin, demonstrating that not only thermal processing, but also mechanical agitation can influence the nutritional value of processed fruit products. During juice homogenization there is oxygen incorporation with oxidation of the vitamin C. In the present study, fruit injured by impact possibly had rupture of internal tissues, which may have caused the exposure of the ascorbic acid to oxygen, accelerating degradation.

Color of the epidermis was not affected by impact, except for 'Montenegrina' tangerines, where hue values differed slightly from the control in the 40 and 60-cm drop treatments (Table 1). No clear tendency for color change with impact was detected, since the other treatments did not show any major modification in color, and the fruit did not show any visually perceptible color alteration.

According to Fischer et al. (2009) there is a positive correlation between impact during processing and the incidence of oleocelloses in 'Valencia' fruits $(r=0.97)$. There was no visual symptom of oleocellosis on the tangerines studied here. When oleocellosis takes place there is usually color modification associated to physiologic stress.

The lack of significant visual modifications in the tangerines submitted to impact suggests that citrus fruit are more resistant to mechanical stress. However, the present experiments provide evidence that tangerines of the Montenegrina and Rainha cultivars, despite not showing visible external modifications, lose important internal quality attributes. As for the two cultivars

Table 1. Hue value of the rind color in 'Montenegrina' and 'Rainha' tangerines exposed to mechanical damage by $\operatorname{impact}^{(1)}$.

\begin{tabular}{lcc}
\hline Treatment & 'Rainha' tangerines & 'Montenegrina' tangerines \\
\hline Control & $74.93 \mathrm{a}$ & $70.04 \mathrm{~b}$ \\
$40 \mathrm{~cm}$ drop & $72.80 \mathrm{a}$ & $71.91 \mathrm{a}$ \\
$60 \mathrm{~cm}$ drop & $74.38 \mathrm{a}$ & $72.04 \mathrm{a}$ \\
$80 \mathrm{~cm}$ drop & $73.20 \mathrm{a}$ & $69.44 \mathrm{~b}$ \\
$100 \mathrm{~cm}$ drop & $73.94 \mathrm{a}$ & $69.84 \mathrm{~b}$ \\
\hline CV $(\%)$ & 2.55 & 0.86 \\
\hline
\end{tabular}

${ }^{(1)}$ Means followed by equal letters, in the column, do not differ significantly by Duncan's test at $5 \%$ probability. Hue value $=[\operatorname{arcotang}(a, b) \times 180] / \pi$. Color parameters $\mathrm{a}$ and $\mathrm{b}$ obtained by colorimeter. Means of three readings per fruit. 
evaluated, Montenegrina, with more response to impact, is more susceptible to mechanical damage.

\section{Conclusions}

1. The impact damages caused by dropping the fruit over rigid surfaces from heights of up to $100 \mathrm{~cm}$ do not induce perceptible color changes on the rinds of 'Montenegrina' and 'Rainha' tangerines.

2. Impacts trigger internal qualitative changes in the fruits of 'Montenegrina' and 'Rainha' tangerines, with significant losses of ascorbic acid contents and increases in the sugar:acid ratio.

3. Fruits of 'Montenegrina' tangerines are more susceptible to internal quality losses than 'Rainha' tangerines.

\section{Acknowledgements}

To Ecocitrus, for providing the fruit to this experiments; and to Coordenação de Aperfeiçoamento de Pessoal de Nível Superior, for the scholarship.

\section{References}

AOAC INTERNATIONAL. Official methods of analysis of AOAC International. Washington: AOAC International, 2002.

COUTO, S.M.; BATISTA, C. da S.; DEVILLA, I.A.; PAIM, V.T. Características de frutos de café sob compressão. Revista Brasileira de Engenharia Agrícola e Ambiental, v.6, p.117-122, 2002.

DURIGAN, M.F.B.; MATTIUZ, B.-H.; DURIGAN, J.F. Injúrias mecânicas na qualidade pós-colheita de lima ácida 'Tahiti' armazenada sob condição ambiente. Revista Brasileira de Fruticultura, v.27, p.369-72, 2005.

FERNANDEZ, R.M.; NORENA, C.P.Z.; SILVEIRA, S.T.; BRANDELLI, A. Osmotic dehydration of muskmelon (Cucumis melo): influence of blanching and syrup concentration. Journal of Food Processing and Preservation, v.31, p.392-405, 2007.

FISCHER, I.H.; FERREIRA, M.D.; SPÓSITO, M.B.; AMORIN, L. Citrus postharvest diseases and injuries related to impact on packing lines. Scientia Agriculture, v.66, p.210-217, 2009.

FISCHER, I.H.; TOFFANO, L.; LOURENÇO, S.; AMORIM, L. Caracterização dos danos pós-colheita em citros procedentes de “packinghouse". Fitopatologia Brasileira, v.32, p.304-310, 2007.

GARCIA, C.; RUIZ, M.; CHEN, P. Impact parameters related to bruising in selected fruits. St. Joseph: American Society of Agricultural Engineers, 1988. 16p.

INSTITUTO FNP. Agrianual 2008: anuário da agricultura brasileira. São Paulo: Instituto FNP, 2008. 502p.

KASAT, G.F.; MATTIUZ, B.-H.; OGASSAVARA, F.O.; BIANCO, M.S.; MORGADO, C.M.A.; CUNHAJUNIOR, L.C. Injúrias mecânicas e seus efeitos em pêssegos 'Aurora-1'. Revista Brasileira de Fruticultura, v.29, p.318-322, 2007.

KAYS, J.S. Postharvest physiology of perishable plant products. New York: Van Nostrand Reinhold, 1991. 532p.

KECHINSKI, C.P. Avaliação do uso de ozônio sobre a conservação do mamão papaia (Carica papaya L.). 2007. 125p. Dissertação (Mestrado) Universidade Federal do Rio Grande do Sul, Porto Alegre.

MAO, L.; YING, T.; XI, Y.; ZHEN, Y. Respiration rate, ethylene production, and cellular leakage of fruit following vibrational stree. HortScience, v.30, p.145-149, 1995.

MATTIUZ, B.-H.; DURIGAN, J.F. Efeito de injúrias mecânicas no processo respiratório e nos parâmetros químicos de goiabas 'Paluma' e 'Pedro Sato'. Revista Brasileira de Fruticultura, v.23, p.282-287, 2001.

MATTIUZ, B.H.; DURIGAN, J.F.; ROSSI JÚNIOR, O.D. Processamento mínimo em goiabas 'Paluma' e 'Pedro Sato': 2. Avaliação química, sensorial e microbiológica. Ciência e Tecnologia de Alimentos, v.23, p.409-413, 2003.

MINOLTA. Precise color communication. Ramsey: Minolta, 1993. 13p. MORETTI, C.L.; SARGENT, S.A.; HUBER, D.J. Delayed ripening does not alleviate symptoms of internal bruising in tomato fruit. Proceedings of the Florida State Horticultural Society, v.112, p.169-171, 1999.

MORETTI, C.L.; SARGENT, S.A.; HUBER, D.J.; CALBO, A.G.; PUSCHMANN, R. Chemical composition and physical properties of pericarp, locule, and placental tissues of tomatoes with internal bruising. Journal of the American Society for Horticultural Science, v.123, p.656-660, 1998.

NAGY, S. Vitamine C contents of citrus fruit and their products: a review. Journal of Agricultural Food Chemistry, v.28, p.8-18, 1980.

PIO, R.M.; FIGUEIREDO, J.O.; STUCHI, E.S.; CARDOSO, S.A.B. Variedades copas. In: MATTOS JUNIOR, D. de; DE NEGRI J.; PIO, R.M.; POMPEU JUNIOR, J. (Ed.). Citros. Campinas: Instituto Agronômico: Fundag, 2005. p.37-60.

PISARCZYK, J.M. Field harvest damage affects potato tuber respiration and sugar content. American Potato Journal, v.59, p.205-211, 1982.

SALVEIT, M.E.; LOCY, R.D. Cultivar differences in ethylene production by wounded sweet potato roots. Journal of the American Society for Horticultural Science, v.107, p.1114-1117, 1982.

SANCHES, J.; DURIGAN, J.F.; DURIGAN, M.F.B. Aplicação de danos mecânicos em abacates e seus efeitos na qualidade dos frutos. Engenharia Agrícola, v.28, p.164-175, 2008.

SAS INSTITUTE. SAS OnlineDoc. Version 9.1.3. Cary: SAS Institute, 2004.

SILVA, P.T. da; LOPES, M.L.M.; VALENTE-MESQUITA, V.L. Efeito de diferentes processamentos sobre o teor de ácido ascórbico em suco de laranja utilizado na elaboração de bolo, pudim e geléia. Ciência e Tecnologia de Alimentos, v.26, p.678-682, 2006.

VIGNEAULT, C.; BORDINI, M.R.;ABRAHÃO, R.F. Embalagem para frutas e hortaliças. In: CORTEZ, L.A.B.; HONÓRIO, S.L.; MORETTI, C.L. (Ed). Resfriamento de frutas e hortaliças. Brasília: Embrapa Hortaliças, 2002. p.96-121.

$\overline{\text { Received on August 6, } 2009 \text { and accepted on November 9, } 2009}$ 